\title{
PENGARUH PENERAPAN MEDIA AUDIOVISUAL TERHADAP PEMAHAMAN KONSEP DAN KETERAMPILAN SOSIAL DALAM PEMBELAJARAN IPS PADA SISWA KELAS VII SMP GANESHA DENPASAR
}

\author{
Ni Nyoman Damayanti ${ }^{1}$, Sukadi ${ }^{2}$, I Wayan Kertih ${ }^{3}$ \\ Program Studi Pendidikan IPS Universitas Pendidikan Ganesha Singaraja \\ e-mail: Damayanti@gmail.com¹, adhys pkn@yahoo.com² ${ }^{2}$, iwayankertih@gmail.com³
}

\begin{abstract}
Abstrak
Penelitian ini bertujuan sebagai berikut. 1. Menguraikan pengaruh penerapan mediaaudiovisual dalam pembelajaran IPS terhadap tingkat pemahaman konsep IPS dan keterampilan sosial siswa secara simultan pada siswa kelas VII SMP Ganesha Denpasar. 2. Menjelaskanpengaruh penerapan media audiovisual dalam pembelajaran IPS terhadap tingkat pemahaman konsep IPS pada siswa kelas VII SMP Ganesha Denpasar. 3. Menjelaskanpengaruh penerapan media audiovisual dalam pembelajaran IPS terhadapketerampilan sosialpada siswa kelas VII SMP Ganesha Denpasar. Untuk mencapa tujuan ini, penelitian ini dilakukan dengan penelitian eksperimen semu menggunakan rancangan the randomized control group with posttest only design pada dua kelas VII di SMP Ganesha Denpasar: satu kelas sebagai kelas eksperimen dan satu kelas sebagai kelas kontrol. Jumlah sampel penelitian ini adalah 79 orang siswa. Ubahan bebas dalam penelitian ini adalah pembelajaran IPS dengan bantuan media audiovisual dan pembelajaran konvensional, sedangkan ubahan terikatnya adalah pemahaman konsep IPS dan keterampilan sosial siswa. Pengumpulan data dalam penelitian ini menggunakan tes objektif pilihan ganda dan form penilaian diri keterampilan sosial. Data hasil penelitian ini dianalisis secara deskriptif dan dengan Manova satu jalur. Hasil penelitian ini menunjukkan sebagai berikut. 1. Ada pengaruh penerapan mediaaudiovisual dalam pembelajaran IPS yang signifikan terhadap tingkat pemahaman konsep IPS dan keterampilan sosial siswa secara simultan pada siswa kelas VII SMP Ganesha Denpasar. 2. Ada pengaruh penerapan media audiovisual dalam pembelajaran IPS yang signifikan terhadap tingkat pemahaman konsep IPS pada siswa kelas VII SMP Ganesha Denpasar. 3. Ada pengaruh penerapan media audiovisual dalam pembelajaran IPS yang signifikan terhadapketerampilan sosialpada siswa kelas VII SMP Ganesha Denpasar.
\end{abstract}

Kata Kunci: Media Audiovisual, pemahaman konsep IPS, dan keterampilan sosial siswa

\begin{abstract}
This study was aimed at explaining the effect of implementing audiovisual aid in social studies teaching toward the level of students concept attainment and social skills simultaneously at students grade VII of SMP Ganesha Denpasar; explaining the effect of implementing audiovisual aid in social studies teaching toward the level of students concept attainment at students grade VII of SMP Ganesha Denpasar; and explaining the effect of implementing audiovisual aid in social studies teaching toward the level of students social skill at students grade VII of SMP Ganesha Denpasar. To achieve these objectives, this study was conducted by quasi experiment in randomized control group with posttest only design at two classes of grade VII SMP Ganesha Denpasar: one class for experiment group and one class for control group. The total samples of this study were 79 pupils. The independent variable of this research was social studies teaching by audiovisual aid and the dependents were the level of social studies concept attainment and the level of students social skill. Data were collected in this study by using multiple choice test and students' social skill selfassessment form. Data were analyzed, then, descriptively and by using Manova. The results of this research revealed that as followed. 1. There was a significant effect of using audiovisual media in Social Studies teaching toward students concept attainment and social skill simultaneously at students grade VII of SMP Ganesha Denpasar. 2. There was a significant effect of using audiovisual media in Social Studies teaching toward students concept attainment at students grade VII of SMP Ganesha Denpasar. 3. There was a significant effect of using audiovisual media in Social Studies teaching toward students social skill at students grade VII of SMP Ganesha Denpasar.
\end{abstract}

Key words: audiovisual, Social Studies concept attainment, and social skill 


\section{PENDAHULUAN}

Kemajuan teknologi yang semakin pesat tidak lepas dari perkembangan bidang IImu Pengetahuan Sosial (IPS) sebagai ilmu dasar dalam mempelajari ekonomi.Usaha meningkatkan Sumber Daya Manusia (SDM) dalam bidang IImu Pengetahuan Sosial (IPS) menjadi tugas penting bagi pemerintah khususnya dalam bidang pendidikan.Mutu pendidikan yang tinggi dalam pendidikan IImu Pengetahuan Sosial (IPS) sangat diperlukan untuk menciptakan Sumber Daya Manusia (SDM) yang mampu bersaing di dunia global.

Mata pelajaran IPS di SMP bertujuan, antara lain: (1) mengenal kehidupan masyarakat dalam berbagai aspek dan lingkungan; (2) memiliki kemampuan dasaruntuk berpikir logis dan kritis, rasa ingin tahu, inkuiri (learning skills), memecahkan masalah, mengambil suatu keputusan, dan keterampilan dalam kehidupan sosial bermasyarakat; (3) memiliki kesadaran terhadap nilai-nilai sosial budaya, kebangsaan, dan kemanusiaan, serta kepribadian yang didasarkan pada nilai-nilai tersebut; dan (4) memiliki kemampuan untuk berkomunikasi, bekerjasama, dan berkompetisi dalam masyarakat yang majemuk di tingkat lokal, nasional, dan global. Begitu kompleksnya tujuan pendidikan IPS yang ingin dicapai, tidak berlebihan jika dikatakan bahwa pembelajaran IPS memiliki fungsi dan peran yang vital dan strategis dalam rangka meningkatkan kecerdasan, keterampilan dan kompetensi sosial untuk menjadi warga negara yang baik yang memiliki pengetahuan, nilai dan sikap, keterampilan, komitmen, kofidensi, kompetensi, dan budaya sosial kewarganegaraan.

Prestasi belajar siswa secara nasional dalam mata pelajaran IPS juga cenderung rendah. Dalam beberapa kasus di sekolah bahkan dilaporkan bahwa prestasi belajar siswa dalam mata pelajaran IPS paling rendah dibandingkan prestasi belajar siswa pada mata pelajaran yang lainnya. Dengan demikian, masih terdapat kesenjangan yang sesungguhnya terjadi antara tujuan pembelajaran IPS di sekolah, termasuk di tingkat SMP, dengan pencapaian prestasi belajar IPS siswa secara nyata. Adanya kesenjangan ini menarik perhatian peneliti untuk melakukan studi tentang prestasi belajar siswa SMP dalam mata pelajaran IPS, khususnya dalam pemahaman konsep dan keterampilan sosial siswa.

Rendahnya hasil belajar IPS siswa dapat ditunjukkan dengan beberapa indikator. Pertama, penguasaan konsep-konsep IPS siswa dapat dikatakan masih cenderung pada level mengingat atau menghafal dan belum memahami dengan baik, apalagi menerapkannya. Kedua, pengembangan kompetensi siswa untuk memiliki kemampuan dasar berpikir logis dan kritis, rasa ingin tahu, inkuiri, memecahkan masalah, dan keterampilan dalam kehidupan sosial dapat dikatakan sangat rendah. Ketiga, pengembangan kompetensi untuk memiliki komitmen dan kesadaran terhadap nilai-nilai sosial dan kemanusiaan juga dapat dikatakan masih sangat rendah. Keempat, pengembangan kompetensi siswa untuk memiliki kemampuan berkomunikasi, bekerjasama,dan berkompetisi dalam masyarakat yang majemuk terutama di tingkat lokal juga masih sangat terbatas. Hal ini terjadi karena dalam pembelajaran oleh guru cenderung lebih berorientasi pada penguasaan fakta dan peristiwa dan kurang mendalami persoalanpersoalan konseptual, hubungan antar konsep, pemecahan masalah, dan kurang menekankan belajar dengan penemuan.

Kondisi pembelajaran IPS yang konvensional tentu dapat menjadi masalah karena kurang membantu pencapaian tujuan pembelajaran IPS secara maksimal dan optimal. Karena itu dibutuhkan strategi alternatif untuk pemecahan masalah tersebut. Rendahnya hasil belajar IPS siswa dikaitkan dengan pembelajaran IPS yang masih bersifat konvensional dan kurangnya dukungan media dan sarana pembelajaran yang dapat menumbuhkan perhatian dan minat belajar siswa.

Media pembelajaran dan sarana pembelajaran sangat penting untuk pencapaian tujuan pembelajaran khususnya pembelajaran IPS. Mengingat bahwa laboratorium IPS yang dapat dipergunakan siswa untuk mempraktekan materi-materi yang disampaikan dikelas. Sarana pembelajaran yang baik, akan dapat membantu efektif dalam pembelajaran IPS dalam melihat realitas kehidupan sehari-hari yang merupakan suatu fenomena sosial.

Sayangnya, dalam realita pembelajaran IPS sehari-hari pada siswa di sekolah, termasuk pada siswa SMP, selama ini guru-guru IPS cenderung hanya menggunakan metode pembelajaran ceramah, tanya jawab, dan pemberian tugas., tanpa didukung dengan 
media pembelajaran yang dapat membantu siswa untuk memahami konsep yang diajarkan (Kertih, 2016). Masih terdapat tenaga pendidik belum menggunakan media pembelajaran yang memanfaatkan kecanggihan teknologi dalam menunjang proses belajar mengajar untuk meningkatkan hasil belajar peserta didik. Hal ini dikarenakan tenaga pendidik belum mampu menyediakan dan membuat media dengan berbantuan teknologi, sehingga peserta didik kurang antusias mengikuti proses belajar mengajar di dalam kelas. Tenaga pendidik masih menggunakan Lembar Kerja Siswa (LKS), buku paket dan pemberian contoh berupa gambar yang masih terbatas.

\section{METODE PENELITIAN}

Rancangan penelitian diperuntukan sebagai pedoman dalam melakukan sebuah penelitian. Rancangan penelitian yang digunakan dalam penelitian ini adalah rancangan penelitian kuantitatif dengan metode eksperimen. Penelitian ini merupakan penelitian eksperimen semu (quasi experiment) terhadap siswa dalamkelas dengan desain secaraacak menggunakan tes akhir saja atau sering disebut denganNon-equivalen control group design atau intak group. Dalam rancangan ini, kelompok eksperimen diberi perlakuan sedangkan kelompok kontrol tidak. Pada kedua kelompok setelah pemberian perlakuan diadakan pengukuran (post test). Kelompok eksperimen dikenai perlakuan pembelajaran dengan media audiovisual dan kelompok kontrol dikenai perlakuan pembelajaran konvensional dalam jangka waktu tertentu. Kemudian kedua kelompok dikenai pengukuran yang sama. Perbedaan hasil pengukuran yang timbul dianggap bersumber dari variabel perlakuan. Dalam penelitian ini peneliti tidak dapat melakukan random pada unit individu. Random dilakukan hanya pada tingkat unit kelas, karean itulah rancangan penelitian ini sering disebut dengan intak group, yaitu kelompok yang terbentuk sudah ada seperti semula tanpa campur tangan peneliti.

Dua kelompok yang ada di awal diberi prates, kemudian diberikan perlakuan yang berbeda, dan terakhir diberikan pascates tetapi skor yang dianalisi hanya skor post test saja

\section{HASIL PENELITIAN DAN PEMBAHASAN}

Dari hasil uji hipotesis ditemukan: 1) hasil uji hipotesis pertama menunjukkan bahwa penerapan media audiovisual dalam pembelajaran IPS dapat mempengaruhi secara signifikan prestasi belajar IPS siswa secara simultan baik pada domain pemahaman konsep maupun keterampilan sosial pada siswa kelas VIISMP Ganesha Denpasar. Hal ini dapat dilihat pada Statistik X (pembelajaran dengan media audiovisual) diperoleh angka-angka signifikansi didasarkan pada Pillai's Trace, Wilk's Lambda, Hotelling's Trace, dan Roy's Largest Root sebesar $0,001<0,05$. Ini berarti $\mathrm{H}_{0}$ yang menyatakan penerapan media audiovisual dalam pembelajaran IPS tidak berpengarus secara signifikan terhadap prestasi belajar IPS siswa secara simultan baik pada domain pemahaman konsep maupun keterampilan sosial pada Siswa Kelas VIISMP Ganesha Denpasar, ditolak. Sebaliknya $\mathrm{H}_{\mathrm{a}}$ yang menyatakan penerapan media audiovisual dalam pembelajaran IPS dapat mempengaruhi secara signifikan prestasi belajar IPS siswa secara simultan baik pada domain pemahaman konsep maupun keterampilan sosial pada Siswa Kelas VIISMP Ganesha Denpasar, diterima. Jadi, dapat disimpulkan bahwa terdapat pengaruh simultan yang signifikan perapan media audiovisual dalam pembelajaran IPS terhadap pemahaman konsep maupun keterampilan sosial pada Siswa Kelas VIISMP Ganesha Denpasar, 2) hasil uji hipotesis kedua berdasarkan statistik "Corrected Model $Y_{i}$ " diperoleh nilai sig. sebesar $0,001<0,05$ sehingga $H_{0}$ ditolak dan $\mathrm{H}_{1}$ diterima. Ini berarti bahwa $\mathrm{Ho}$ yang menyatakan penerapan media audiovisual dalam pembelajaran IPS tidak mempengaruhi secara signifikan prestasi belajar IPS siswa pada domain pemahaman konsep IPS pada Siswa Kelas VIISMP Ganesha Denpasar, ditolak. Sebaliknya Ha yang menyatakan penerapan media audiovisual dalam pembelajaran IPS dapat mempengaruhi secara signifikan prestasi belajar IPS siswa pada domain pemahaman konsep IPS pada siswa kelas VIISMP Ganesha Denpasar, diterima. Jadi dapat disimpulkan bahwa terdapat pengaruh yang signifikan perapan media audiovisual dalam pembelajaran IPS terhadap pemahaman konsep IPS 
siswa kelas VIISMP Ganesha Denpasar, dan 3) hasil uji hipotesis ketiga berdasarkan statistik "Corrected Model $Y_{2}$ " diperoleh nilai sig. sebesar $0,001<0,05$ sehinggaH ${ }_{0}$ ditolak dan $\mathrm{H}_{1}$ diterima. Ini berarti bahwa Ho yang menyatakan penerapan media audiovisual dalam pembelajaran IPS tidak mempengaruhi secara signifikan prestasi belajar IPS siswa pada domain keterampilan sosial pada siswa kelas VII SMP Ganesha Denpasar, ditolak. Sebaliknya Ha yang menyatakan penerapan media audiovisual dalam pembelajaran IPS dapat mempengaruhi secara signifikan prestasi belajar IPS siswa pada domain keterampilan sosial pada siswa kelas VIISMP Ganesha Denpasar, diterima. Jadi dapat disimpulkan bahwa terdapat pengaruh yang signifikan perapan media audiovisual dalam pembelajaran IPS terhadap keterampilan sosial siswa kelas VIISMP Ganesha Denpasar.

Temuan yang diperoleh dalam penelitian tesis iniperlu mendapat pembahasan lebih lanjut satu persatu. Pertama, temuan pertama penelitian ini menyimpulkan bahwaterdapat perbedaan prestasi belajar dalam domain pemahaman konsep IPS dan keterampilan sosial siswa yang signifikan secara simultan dalam pembelajaran IPS siswa kelas VII SMPGanesha Denpasar antara siswa yang dibelajarkan dengan menggunakan media audiovisual dan siswa yang dibelajarkan secara konvensional. Temuan pertama penelitian ini tentu sangat sesuai dengan harapan peneliti berdasarkan kajian teori dan temuan hasil penelitian terdahulu yang relevan.

Sesuai dengan landasan teori dan temuan penelitian yang dijadikan kerangka berpikir dalam penelitian, maka temuan pertama penelitian ini dapat dibahas sebagai berikut. Pembelajaran IPS dengan audio visual diyakini dapat membantu siswa meningkatkan hasil belajarnya secara terintegrasi baik pada domain pemahaman konseptual maupun pada domain keterampilan sosial siswa (Purwanti, 2015). Hubungan ubahan-ubahan ini bisa dikaji baik menggunakan dasar teori pengolahan informasi maupun dasar teori konstruktivisme. Menurut teori pengolahan informasi, informasi yang dipelajari siswa dapat diterima siswa lebih mudah dan lebih lama, jika informasi disusun secara bermakna dan bukan secara terlepas-lepas. Suatu informasi dikatakan lebih bermakna adalah jika informasi tersebut tersusun sedemikian rupa menjalin suatu pengertian yang utuh. Sebagai contoh, siswa akan lebih mudah mengerti prinsip-prinsip ekonomi dan kandungan konsep-konsep di dalamnya daripada harus mengingat nomor hp yang angka-angkanya tidak memiliki hubungan satu sama lain. Demikian pula, informasi akan lebih mudah dikuasai siswa jika informasi tersebut dapat diterima lebih konkrit dari pada yang bersifat abstrak (Gredler, 1992).

Menurut teori pengolahan informasi pula, informasi yang utuh dan bermakna dapat disusun sedemikian rupa menggunakan suatu model hubungan antar konsep baik menggunakan model hubungan verbal, model hubungan gambar statis, model hubungan gambar bergerak, model hubungan audio, maupun perpaduan diantaranya (Sukadi, 2010). Dengan informasi yang disusun secara bermakna akan memberikan pengertian yang lebih utuh dan mudah kepada siswa, jika dibandingkan dengan informasi yang dipisah-pisahkan tanpa makna (NCSS, 2000). Informasi yang bermakna tidak saja lebih mudah disimpan di memori jangka pendek yang bersifat aktif, sehingga siswa lebih mudah mengingat atau menghafalnya; tetapi juga lebih mudah dimengerti dan bersifat tahan lama diproses di memori jangka panjang yang bersifat pasif (Sukadi, 2016).

Pembelajaran IPS menggunakan bantuan media audiovisual dapat membantu guru menyusun materi pelajaran IPS menjadi informasi yang lebih bermakna (DBE, 2010). Dengan bantuan media audiovisual guru dapat saja, misalnya, mengembangkan satu model advance organizer dalam bentuk satu peta konsep besar yang menghubungkan konsepkonsep yang dipelajari siswa baik secara model hubungan verbal maupun model hubungan verbal dan gambar statis dan gambar bergerak (Sukadi, 2010). Jika ini dapat dilakukan guru dalam penggunaan media audiovisual pembelajaran IPS, tentu ini akan memudahkan siswa mengingat dan mengerti pelajaran secara bermakna. Sebagai contoh, guru membelajarkan siswa tentang motiv ekonomi dengan membuat peta konsep hubungan motiv yang satu dengan motiv ekonomi lainnya secara terstruktur. Guru dapat membuat satu model hubungan verbal dan gambar statis atau gambar bergerak yang menceritakan secara eksplanatif berbagai peristiwa motiv ekonomi tersebut di dalam media pembelajaran IPS yang digunakannya. Dengan begitu siswa akan lebih mudah mengerti materi pelajaran 
tersebut dibandingkan jika siswa hanya mendengar ceramah dari guru. Informasi yang diterima siswa tidak saja bermakna, tetapi tersusun sedemikian rupa menjadi lebih menarik perhatian siswa. Suatu informasi jika diperhatikan lebih lama karena siswa tertarik memperhatikannya, tentu akan memberikan hasil belajar pemahaman konseptual yang lebih baik pula (Sukadi, 2009, 2010, 2011).

Hubungan antara penggunaan mediaaudiovisual dalam pembelajaran IPS dengan hasil belajar siswa juga dapat dijelaskan menggunakan dasar teori konstruktivisme. Menurut teori konstruktivisme siswa belajar membangun sitem pengetahuannya sendiri secara mandiri atau kelompok secara aktif dengan berbasis pada pengalaman atau pengetahuan awal yang dimilikinya. Menurut teori konstruktivisme, belajar bukanlah proses pentransferan ilmu yang sudah jadi dari kepala guru ke pikiran siswa. Belajar adalah proses yang aktif oleh siswa sendiri dengan menggunakan pengalaman-pengalamannya baik secara individu maupun kelompok dalam belajar beradaptasi pada lingkungan sekitarnya (Sadia, 1996; Suparno, 1997).

Belajar IPS dengan bantuan media audiovisual dapat membantu siswa belajar dengan iklim belajar konstruktivisme yang aktif. Dalam hal ini guru IPS dapat menyusun proses dan materi pembelajaran IPS yang memungkinkan siswa dapat berinteraksi aktif selama proses pembelajaran dengan materi pembelajaran baik secara individu maupun kelompok (Sukadi, 2006). Untuk ini, melalui mediaaudiovisual pembelajaran, materi pelajaran tidak disusun dalam struktur yang sudah jadi, melainkan disusun dalam bentuk masalah yang harus dipecahkan oleh siswa. Dalam materi media, misalnya, guru menunjukkan gambar-gambar atau photo-photo berbagai motiv ekonomi. Kepada siswa kemudian diminta untuk mengklasifikasi dan menyusun berbagai photo tersebut secara sistematis menurut kelompok motiv ekonomi dan lalu siswa diminta menjelaskan hasil pengelompokan tersebut. Dalam media pembelajaran tersebut juga bisa disuguhkan tugastugas belajar yang harus dikerjakan siswa baik secara personal maupun kelompok. Dengan begitu siswa akan belajar lebih bermakna berbasis masalah yang memungkinkan siswa membangun sendiri pengetahuannya sesuai dengan pengalamannya.

Dalam iklim belajar secara konstruktivis seperti ini, siswa tidak saja belajar secara akademis, melainkan dapat juga melakukan studi sosial dengan mengembangkan berbagai sikap dan keterampilan sosial, bahkan melakukan studi aktivitas moral (bandingkan dengan DeVries dan Zan, 1994). Studi akademis dilakukan siswa dengan memenuhi semua tugas akademis yang diatur dalam muatan media audiovisual. Studi sosial dilakukan siswa dengan melakukan interaksi aktif dengan media pembelajaran dan guru baik secara personal maupun secara berkelompok. Untuk ini dapat dikembangkan bentuk media pembelajaran yang interaktif. Dengan studi sosial inilah siswa juga belajar mengembangkan nilai-nilai dan sikap serta keterampilan sosial yang penting dalam pembelajaran IPS, seperti: keterampilan berkomunikasi, melakukan presentasi, bekerja sama dalam kelompok, sharing tanggung jawab kepemimpinan, belajar mendistribusikan tugas, belajar bernegosiasi, belajar mempengaruhi orang lain, belajar memecahkan masalah bersama, dan belajar bertanggungjawab bersama (Martorella, 1994). Dalam kondisi belajar yang demikian siswa juga belajar melakukan studi aktivtas moral (Sukadi, 2009, 2010, 2011). Terintegrasinya ketiga jenis studi ini dengan bantuan media audiovisual pembelajaran, dapat membuat hasil belajar siswa menjadi lebih terintegrasi dan bermakna tidak saja dalam menguasai konsepkonsep IPS secara bermakna, tetapi juga dapat mengembangkan niai-nilai dan sikap sosial, serta mengembangkan keterampilan sosial tertentu (DeVries dan Zan, 1994; Kemahyasa, 2012).

Sesuai dengan tingkat perkembangan kognisi siswa, siswa dapat belajar dengan mudah, menurut teori kognisinya Piaget (Gredler, 1992) mulai dari objek yang kongkret ke objek yang abstrak untuk membangun sistem pengetahuan yang formal dan abstrak (Suparno, 1997). Untuk anak-anak di Indonesia, diakui bahwa kemampuan berpikir siswa cenderung masih bersifat aktif pada objek-objek yang kongkret. Pembelajaran IPS dengan bantuan media pembelajaran yang bersifat audiovisual dapat membantu siswa belajar dari berpikir kongkret ke berpikir abstrak. Di sini media audiovisualdapat membantu siswa memperoleh pengetahuan konsep-konsep IPS secara kongkret (Hanim, et al., 2016; 
Hikmah,2013). Di sini siswa dapat menggunakan seluruh inderanya (pendengaran, penglihatan, dan gerak) untuk memperoleh pengetahuan secara nyata dan asli dari berbagai model yang divisualisasikan dan diaudiokan serta digerakkan baik dengan gerak animasi maupun gerakan psikomotor yang nyata dalam media. Menurut pakar media pembelajaran, pembelajaran yang memungkinkan siswa dapat secara aktif memanfaatkan seluruh indera pendengaran, penglihatan, penciuman, pengecapan, perabaan/merasakan, dan indera gerak taktil melalui media audiovisual dapat meningkatkan jumlah dan kualitas informasi yang diterima (Hanim, et al., 2016: 752-757; Rusman, et al., 2011; Rusman, 2012).

Temuan kedua penelitian ini adalah bahwa terdapat perbedaan prestasi belajar dalam domain pemahaman konsep IPS siswa yang signifikandalam pembelajaran IPS siswa kelas VII SMP Ganesha Denpasar antara siswa yang dibelajarkan dengan menggunakan media audiovisual dan siswa yang dibelajarkan secara konvensional. Temuan kedua penelitian ini tentu makin menguatkan keyakinan peneliti bahwa pembelajaran IPS menggunakan bantuan media memang sangat efektif meningkatkan prestasi belajar siswa dalam aspek pemahaman konsep IPS siswa. Hasil penelitian ini tentu semakin kuat mendukung temuan-temuan sebelumnya yang meneliti pengaruh penggunaan media audiovisual dalam pembelajaran terhadap tingkat pemahaman konsep IPS siswa pada khususnya dan pembelajaran di kelas pada umumnya (Sudarsono, 2012; Budyartati, 2008); Fita Lestari, 2013; Kartikasari, 2016).

Temuan ketiga penelitian ini adalah bahwa terdapat perbedaan prestasi belajar dalam domain keterampilan sosial siswa yang signifikan dalam pembelajaran IPS siswa kelas VII SMP Ganesha Denpasar antara siswa yang dibelajarkan dengan menggunakan media audiovisual dan siswa yang dibelajarkan secara konvensional. Temuan ketiga penelitian ini juga tentu makin menguatkan keyakinan peneliti bahwa pembelajaran IPS menggunakan bantuan media audiovisual memang sangat efektif meningkatkan prestasi belajar siswa dalam aspek keterampilan sosial siswa. Hasil penelitian ini tentu semakin kuat mendukung temuan-temuan sebelumnya yang meneliti pengaruh penggunaan media audiovisual dalam pembelajaran IPS terhadap tingkat keterampilan sosial siswa pada khususnya (Dinasari Haryono, 2015).

Dari seluruh pembahasan di atas dapatlah disimpulkan bahwa pembelajaran IPS dengan menggunakan bantuan media audiovisual dapat efektif dan signifikan mempengaruhi tingkat pemahaman konsep IPS dan keterampilan sosial siswa baik secara simultan maupun secara sendiri-sendiri pada siswa kelas VII SMP Ganesha Denpasar.

\section{SIMPULAN DAN SARAN}

Berdasarkan hasil pengujian hipotesis seperti disajikan pada Bab IV, dalam penelitian ini diperoleh simpulan sebagai berikut. 1) penerapan media audiovisual dalam pembelajaran IPS dapatmempengaruhisecarasignifikanprestasibelajar IPS siswa secara simultan baik pada domain pemahaman konsep maupun keterampilan social pada Siswa Kelas VIISMP Ganesha Denpasar, penerapan media audiovisual dalam pembelajaran IPS dapat mempengaruhi secara signifikan prestasi belajar IPS siswa dalam domain pemahaman konsep pada Siswa Kelas VIISMP Ganesha Denpasar, dan 3) penerapan media audiovisual dalam pembelajaran IPS dapat mempengaruhi secarasignifikanprestasibelajar IPS siswadalam domain keterampilan social padaSiswaKelas VIISMP Ganesha Denpasar.

Berdasarkan temuan diatas, kesimpulan dalam penelitian in iadalah bahwa berbantuan media audiovisual lebih unggul dibandingkan pembelajaran konvensional tanpa bantuan media audiovisual dalam halhasil belajar IPS. Berkenaan dengan hasil penelitian yang diperoleh, ada beberapa saran yang dapat diajukan adalah sebagai berikut, Penelitian ini menunjukkan bahwa pemahaman konsep IPS dan keterampilan sosial siswa yang mengikuti pembelajaran berbantuan media audiovisual lebih baik daripada pemahaman konsep IPS dan keterampilan sosial siswa yang mengikuti pembelajaran konvensional, yaitu tanpa bantuan media audiovisual. Untuk itu,pembelajaranberbantuan media audiovisual perlu dikenalkan dan dikembangkan lebih lanjut kepada para guru, siswa dan praktisi pendidikan lainnya sebagai salah satu alternatif pembelajaran, Penelitian lanjutan yang 
berkaitan dengan pembelajaran bantuan media audiovisual perlu dilakukan dengan materimateri IPS yang lain dengan melibatkan sampel yang lebih luas.

\section{DAFTAR RUJUKAN}

Budyartati, S. 2008. Keefektifan Multimedia Berbasis Komputer Untuk Pembelajaran IImu Pengetahuan Sosial Kelas IV SD Percobaan II Depok Sleman. download.portalgaruda.org/article.php?Diunduh 15 Januari 2018.

DBE. 2010. Pembelajaran Aktif di Perguruan Tinggi. Jakarta: Kerja sama Kementerian Pendidikan dan Kebudayaan dan DBE.

DeVries, R. dan Zan, B. 1994. Moral Classrooms, Moral Children: Creating a Constructivist Atmosphere in Early Education. New York and London: Teachers College Press.

Fita Lestari, R. 2013. Pengaruh Media Kartu Bergambar terhadap Hasil Belajar IPS pada Siswa Kelas IV SD Negeri Kotagede 5 Yogyakarta. Skripsi (tidak dipublikasikan). Yogyakarta: UNY.

Gredler, M. E. 1992.Learning and Instruction: Theory into Practice. Second Edition. New Jersey: Prentice-Hall, Inc.

Hanim F. dkk. 2016. Pengaruh Penggunaan Multimedia Pembelajaran Interaktif Penginderaan Jauh Terhadap Hasil Belajar Geografi. Jurnal Pendidikan: Teori, Penelitian, dan Pengembangan Vol. 1 No. 4 April 2016 Hal.: 752-757.

Hikmah, et al. 2013. Pengembangan Multimedia dalam Pembelajaranllmu Pengetahuan Sosial (IPS) untuk PerolehanBelajar Menghubungkan Konsep pada SiswaKelas VII Madrasah Tsanawiyah Negeri IPontianak. Tesis (tidak dipublikasikan). Pontianak: Universitas Tanjungpura.

Kartikasari, G. 2016. "Pengaruh Media Pembelajaran berbasis Multimedia Terhadap Motivasi dan Hasil Belajar Materi Sistem Pencernaa: Studi eksperimen pada siswa kelas V MI Miftahul Hunda Pandatoyo". Jurnal Dinamika Penelitian Volume 16, Nomor 1 (hal. 6281)

Kemahyasa, I K. 2012. Pengembangan Multimedia interaktif menggunakan Model Borg And Gall Untuk Pelajaran Produktif Menggabungkan Fotografi Digital Ke dalam Sajian Multimedia Di SMK Negeri 3 Singaraja. Tesis (tidak dipublikasikan). Singaraja: Program Pascasarjana Undiksha.

Martorella, P. H. 1985. Elementary Social Studies: Developing Reflective, Competent, and Concerned Citizens. Boston, Toronto: Little, Brown and Company.

Nurhayati dan Susila Purwanti, R. 2016. Upaya Meningkatkan Pemahaman Konsep IPS dengan Model Pembelajaran Kooperatif Tipe Student Facilitator And Explaining pada Siswa Kelas V di SDd 2 Kadipiro Kasihan Bantul Tahun 2015/2016. Diunduh pada Hari Senin, !5 Mei 2017.

1994. Social Studies for Elementary School Children: Developing Young Citizen. New York: Macmillan College Publishing Company.

NCSS, 2000. National Standards for Social Studies Teachers, Volume 1. Washington, DC: National

Purwanti, E. 2015. "Pengembangan Instrumen Keterampilan, Pengaruh Model Pembelajaran Kooperatif Tipe STAD Terhadap Minat dan Prestasi Belajar IPS Pada Siswa Kelas IV Sekolah Dasar No. 3 Legian_Badung, Jurnal Pendidikan Dasar, Volume 3 Tahun 2013.

Rusman, 2012. Model-model Pembelajaran: Mengembang-kan Profesionalisme Guru, RajaGrafindo Persada, Jakar-ta

Rusman,dkk.2011. Pembelajaran Be-rbasis Teknologi Informasi dan Komunikasi.Jakarta: Rajawalipress

Sadia, I W. 1996. Pengembangan Model Belajar Konstruktivis dalam Pembelajaran IPA di Sekolah Menengah Pertama (SMP): Suatu Studi Pembelajaran IPA dalam Pandangan 
Paradigma Konstruktivisme di SMP Negeri di Singaraja. Disertasi (Tidak dipublikasikan). Bandung: Program Pascasarjana IKIP Bandung.

Sriariati, G A K. 2009. Penerapan Model Pembelajaran Keterampilan Proses Sosial untuk Meningkatkan Kualitas Proses dan Hasil Belajar IPS Siswa Kelas V Sekolah Dasar Nomor 2 Mambal. Tesis (Tidak dipublikasikan). Singaraja: Undiksha.

Sri Darmawati, I G A P. 2016. Meningkatkan Hasil Belajar IPS melalui Pembelajaran Kooperatif Berbasis Kearifan Lokal Catur Asrama pada Siswa Kelas VI SD Negeri 1 Astina. Jurnal IKA Undiksha.

Sudarsono. 2012. Penggunaan Multimedia Interaktif untuk Meningkatkan Pemahaman Konsep Perubahan Lingkungan Fisik pada Siswa Kelas IV SD Negeri 6 Jimbung Klaten. Skripsi (tidak dipublikasikan). Surakarta: UNS.

Sugiyono, 2011. Metode Penelitian Kuantitatif Kualitatif dan R\&D. Bandung. Alfabeta.

Suirja, I N. 2009. Pengaruh Model Pembelajaran Keterampilan Proses Sosial terhadap Pemahaman Konsep dan Sikap Sosial Siswa Kelas V Sekolah Dasar di Gugus IV Selemadeg Barat Kabupaten Tabanan. Tesis (Tidak dipublikasikan). Singaraja: Undiksha.

Sukadi. 2016. Lahan Basah: Ekosistem, Pemanfaatan, Masalah, dan Pemecahannya (Suatu Kajian Ekopedagogi pada Pembelajaran IPS di Indonesia). Makalah. Disampaikan pada Seminar Nasional Program Pascasarjana Universitas Lambung Mangkurat yang Diselenggarakan pada tanggal 25 Nopember 2016 di Banjarmasin.

2011. Rekonstruksi Pemikiran Belajar dan Pembelajaran PKN SDsebagai Yadnyadalam rangka Perwujudan Dharma Agamadan Dharma Negara Berbasis Konstruktivisme. Laporan Penelitian Tahun Ke-3 (Tidak dipublikasikan). Singaraja: Undiksha.

....... 2010. Rekonstruksi Pemikiran Belajar dan Pembelajaran PKN SDsebagai Yadnyadalam rangka Perwujudan Dharma Agamadan Dharma Negara Berbasis Konstruktivisme. Laporan Penelitian Tahun Ke-2 (Tidak dipublikasikan). Singaraja: Undiksha.

2006, Pendidikan IPS sebagai Rekonstruksi Pengalaman Budaya Berbasis Ideologi Tri Hita Karana. Disertasi (Tidak dipublikasikan). Bandung: UPI.

Suparno, P. 1997. Filsafat Konstruktivisme dalam Pendidikan.Yogyakarta :Kanisius

Winataputra, U. S. 2001. Jati diri Pendidikan Kewarganegaraan sebagai Wahana Sistemik Pendidikan Demokrasi (Suatu Kajian Konseptual dalam Konteks Pendidikan IPS). Disertasi (Tidak dipublikasikan). Bandung: Universitas Pendidikan Indonesia. 